\title{
1. Introduction to the Handbook of Critical International Relations
}

\author{
Steven C. Roach
}

Over the years, critical international relations (IR) theorists have drawn on a range of thinkers (Karl Marx, Theodor Adorno, Max Horkheimer, Michel Foucault, Judith Butler, and Roy Bhaskar) to critique the structural forces of power, authority, and norms in world politics. Their critical interventions have allowed us to interrogate the sources of exclusion, violence, and subjugation and to devise radical strategies for resisting such domination. This in turn has greatly expanded our critical knowledge of the contradictions (i.e., economic growth that results in an increasing rate of inequality) and tensions driving the struggle for global justice and equality. But the question that many critical IR theorists face today is how to address the growing intensity of these tensions and emotions in global politics. Indeed, one could argue that it is precisely this growing intensity that makes critical theory such an indispensable source of understanding the emancipatory potential of world politics. This Handbook is an attempt to confront this larger challenge by reinterpreting the meaning and relevance of critical theory against today's changing events.

Although critical IR theory came into existence in the 1980s, critical theory's roots can be traced to Enlightenment thought and the radical ideas that emerged out of nineteenth and twentieth century struggles for social equality. For many Enlightenment thinkers, championing reason and science (or scientific reason) meant advancing a new secular society and ending human suffering. The idea was that equal treatment and dignity of all persons could promote universal justice and moral inclusion. By eliminating all vestiges of class privilege, then, society would come to realize the full potential of humanity, including the humane benefits of equal respect and human dignity. However, with the rise of totalitarianism in the mid-twentieth century, the viability of this ideal was no longer certain. For the Frankfurt Institute of Social Research (or Frankfurt School), the rise of Nazism marked an existential threat to this emancipatory project. To confront this threat, one needed new concepts to understand the full extent of the societal problem. In particular, one had to recognize that humanity was not simply an ideal but an open totality of society, that is, an open-ended assemblage of social and historical forces that constituted the intersubjectivity of identity, interests, cultural norms, and beliefs. ${ }^{1}$ In this way, the Frankfurt School based much of its critique of society on its critical opposition to

1 The term "critical theory" was first coined in 1937 by Max Horkheimer, one of the founders of the Frankfurt School. 
positivism (an approach to society in which empirical knowledge is verified by facts and numbers that exists independently of human experience), which, according to Horkheimer, turned reason into a tool for advancing technology at the expense of humanity as a whole (Horkheimer, 1992). The Frankfurt School, it could be said, furnished a complex and dynamic critique of positivism, one that has helped inspire many critical theorists in IR to work beyond the limits (and regressive tendencies) of positivism.

Indeed, to be a "postpositivist" in IR is to critique the limits of scientific and rationalist approaches. It is to confront and engage the hidden effects and tendencies of dogmatism and militant orthodoxy in world politics. Today, the task of engaging these effects involves a series of challenges that threaten democratic values and humanity, more broadly. This Handbook seeks to address these challenges and the implications they raise for sustaining an open-ended critique of global society. It does so in four parts: (I) approaches and emancipation, (II) concepts and configuration, (III) political economy and domination, and (IV) global transformations and challenges. By analyzing the themes of otherness, authoritarian neoliberalism, non-Western sources of international thought, agonistic recognition, and critical animal studies, it aims to appeal to scholars, theorists, and students interested in using critical IR to research the changing dynamics of authority (governance), oppression, and emancipation.

\section{PART I: APPROACHES AND EMANCIPATION}

Broadly speaking, critical theory is comprised of various strands of thought, including Marxist/Hegelianism, Western Marxism, Freudianism, cultural aesthetics, and Weberian thought. Many of the first-generation Frankfurt School thinkers (Max Horkheimer and Herbert Marcuse) who fled Nazi Germany in the 1930s for the United States (Columbia University) were able to formulate the new concepts of negative dialectics and one-dimensional man that synthesized these four strands of thought. However, in time, the negativity of dialectics would eventually outstrip the progressive qualities of critical theory and its orientation to political transformation and democratic freedom. In short, the first-generation thinkers had abandoned the progressive ideals of the Enlightenment and embraced a deep and even dark cynicism toward emancipation.

The early Frankfurt School's focus on the limited potential of the political consciousness led to an important turn in critical theory: namely from consciousness to communicative action. The turn involved focusing on argumentation and discursive reason (rationality based on moral and persuasive reasoning) to understand both the struggle and potential for justice and democracy. Habermas, for instance, situated reason within the communicative action or the pragmatic struggle to live by the force of the better of argument (Habermas, 1984) (he would later apply his ideas to the European Union). The turn also coincided with a renewed interest in Antonio Gramsci, the twentieth-century Italian socialist, and his notions of counter-hegemony 
and historical bloc. In the context of IR during the 1980s, Robert Cox, Richard Ashley, Rob Walker, and Stephen Gill were just a few of the early thinkers to explore and extend these ideas to the international sphere.

In time, their critical interventions would become part of the so-called "Third Debate" (or "fourth," if one counts the earlier inter-paradigm debate) in IR, which centered around the distinction between positivism and post-positivism and drew on the opposition between epistemology (representation and interpretation) and ontology (science and immutable structures) (Lapid, 1989). The Third Debate, it could be argued, reflected the emergence of an open, yet rigorous pluralism in the field and the growing acceptance of the limitations of scientific and rationalist thought; hence the need for alternative approaches to interpret the growing complexity of global politics (e.g., identity, marginalization, and the rising influence of human rights, democracy, and nonstate actors).

The Third Debate also encompassed the critical, normative turn in IR theory in which critical theorists turned to political theory to configure the global transformations of rights, autonomy, citizenship, community, and legitimacy (of sovereign authority). Many of these thinkers drew on the works of Immanuel Kant, Charles Taylor, Axel Honneth, and Habermas to conceptualize the legitimacy and discursive rationality of institutions and agents (Diez and Steans, 2005; Risse, 2000; Haacke, 1996). The idea of this normative turn was that in the age of rapid globalization, the democratic transformation of institutions required us to move beyond the limits of the state and to refigure the cosmopolitan possibilities of individual freedom, from both a radical and pragmatic perspective (Linklater, 2008). In this sense, Habermas's ideas have exercised considerable influence on this normative perspective in critical IR theory.

Chapter 3 critically examines this influence. Here, Ben Thirkell-White shows how Habermas, while vague on political economy issues, shed critical light on the very liberal norms that seemed to separate and isolate economics from politics. He claims that Habermas's commitment to the possibility of rational persuasion left gaps in his thought, and that this might explain his limited popularity in contemporary critical circles. Rather than treating post-structuralist thought as antithetical to Habermas's pragmatic project, Thirkell-White argues that Habermas's ideas provide an important corrective to these ideas, despite his tenuous descriptions of dialogue in terms of an exchange of reasons. Effective inter-subjective communication, he goes on to argue, will be a slow, difficult transformative process, which, under present, contemporary circumstances, needs to be thought through. This means confronting the tendency for "democratic" debates to appear "equal" from a privileged perspective: for it is not enough for political theorists to wait for "progressive ideas" to emerge and triumph. Indeed, these very ideas will shape progressive democratic and economic change, requiring further development before they can make themselves heard.

What is thus required, Thirkell-White contends, is a richer synthesis of moral theory and historical materialism to understand the role of moral obligation in global society (and its constituent parts, notably, human rights, solidarity, democracy, and social equality). Indeed, for the normative turn to become more complete, it also 
must counter the positivist critique and its focus on scientific rigor or the dichotomy between scientism and interpretivism in IR. In this way, it would, as he concludes, represent a self-critical lens of the production of identities and rigid boundaries between subject and other.

In her chapter on the non-Western subject, Pinar Bilgin addresses the unmet goals of opening these boundaries to further critique. She argues that otherness and the international has tended to reinforce longstanding biases against political and cultural values and identities. Otherness is a term that is all too often inscribed within the dominant critical discourses of IR which evaluate and appraise the need for inclusion. If the international is to become a prevailing means of contesting the boundaries of IR, then, as Pinar Bilgin insists, it needs to deconstruct the patriarchal structure of the IR discipline and expose the marginalization of identities in the developing world. In the end, this strategy is needed to counter the rationalist structure of IR.

In Chapter 5, Simon Koschut analyzes this dimension in terms of a critical approach to emotions (or critical emotions). Working within a constructivist lens, he argues that critical emotions research must be deepened to address the question of how emotion should be examined critically in international politics. For the most part, researchers are mainly interested in how emotions are linked to power and marginalization, boundary-making, and the politics of difference. The challenge, however, lies in capturing the communal sentiment that informs the resistance to authority and power. Conversely, social movements, such as the World Social Forum or the lesbian, gay, bisexual, and transgender (LGBT) community are built on strong sentiments of resistance and empowerment, which, in turn, create the possibility for various avenues of emotional resistance or transnational protests and social movements, such as Occupy Wall Street and the "Me-too" debate. The idea is that such marginalized groups and individuals can and often do mobilize collective resistance as communities of feelings. They do so by "naming" emotionally appraised global inequalities and "shaming" those deemed responsible for their underprivileged status.

In Chapter 4, Columba Peoples argues for a return to the Frankfurt School to enhance Critical Security Studies as an approach capable of engaging many of today's global security challenges. His aim is to examine the implications and possibilities of Critical Security Studies as a specific branch of scholarship. Here, he focuses on how the concept of "emancipation" and "immanent critique" can be viewed more prominently. Peoples identifies a potential "negativist" approach to emancipation and security, an approach based on what he calls the dynamic politics of emancipation, which he treats as innately bound up with the identification and critique of human security. The issue that this approach raises is whether security and protection from violence require an extended or open-ended exploration of the political consciousness and emotion.

Lastly, in turning attention to the ontology of critical realism, in particular Roy Bhaskar's critical realism, Ben Luongo addresses a larger ontological problem in critical IR: the limitations of both positivist and post-positivist approaches. Here, Luongo explores the problem(s) of causality in neorealism, which has long advocated for a more complex and multivariate understanding of causal relations in IR, as well 
as Alexander Wendt's distinction between constitutive and causal analysis. In reducing the ontology of international politics to the cultures of anarchy, Wendt's social theory of international politics fails to articulate a mind-independent reality that can avoid the trap of Bhaskar's epistemic fallacy. Through this critical lens, then, Luongo discusses how critical realism diagnoses the limitations of the empiricist tenets that underpin both the positivist and post-positivist approaches to social science. Asserting that all knowledge derives from sense-experience, he concludes that empiricism advocates for a science predicated on methods of observation. However, in reducing the ontology of international politics to discourse and ideas, it fails to articulate a mind-independent reality and, as such commits the epistemic fallacy.

\section{PART II: CONCEPTS AND CONFIGURATION}

In critical IR there is perhaps no more important concept than dialectics. The term has become more, not less, important in terms of conveying the building tensions and mounting pressures in global politics (Brincat, 2014; Brincat et al., 2012; Roach, 2010, 2007; Heine and Teschke, 1996). In Chapter 7, Shannon Brincat and Susan de Groot Heupner focus on the various ways of opening up dialectics. In doing so, they contend that in dialectical thinking there is developing shared interest to broaden the epistemological basis of the discipline by including far older, non-Western forms of dialectical thought (e.g., "worlded"). This suggests that developing derivative discourses from non-Western approaches, which merely reflect the concepts and assumptions of Western IR theory, requires new grounds or forms of thinking into our world. Their analysis thus builds on the overlooked vitality of dialectics in IR, including the analytical value of Axel Honneth's and Hegel's recognition theory or identity logic to configure current conflicts and movements.

Hegel's identity logic in this sense holds important implications for rethinking recognition in international politics. Kate Schick takes up this issue in Chapter 8, which offers an agonistic reading of recognition in IR. At the heart of recognition theory, Schick explains, is an emphasis on relationality, that is, on human beings not as atomized individuals but as socially situated beings. Recognition theory's relational ontology provides an important counterpoint to mainstream narratives of global politics. At present, however, the transformative potential of recognition theory in IR has failed to be fully realized. This is largely due to the dominance of overly teleological and insufficient political conceptions of recognition. In order to get beyond these limitations, Schick argues, IR scholars need to recover an agonistic conception of recognition if its critical potential is to be realized more fully.

In the following chapter, Alexander Barder examines the concept of "empire" through the historical and contemporary effects that imperial practices have had upon domestic space. Because IR theory largely reifies the distinction between the domestic and international, many scholars have missed the wide-ranging historical and contemporary connections that have accrued between colonial domains and metropolitan institutions. Barder takes up two examples: barbed wire and its pro- 
liferation as a technology of enclosure, and contemporary instances of surveillance technologies being marketed to US police departments. He argues that barbed wire has been little understood as a symbol of imperial overreach. Yet, in this way, it also underscores the need to conceptualize a set of material transformations that can link core and periphery, and that takes into account the surplus of such (neo)colonial technologies and their effects.

The oppressive forces of empire return us to the troubling effects of instrumental reason or how reason can be used in multiple ways to justify oppression in the name of moral or civilizing progress. In Chapter 10, Matthew Fluck provides such a re-presentation by confronting some of the gaps in IR's engagement with instrumental reason. Fluck's detailed yet sympathetic account of the Frankfurt School's critique starts by reconstructing the idea of instrumental reason from within the writings of Marx, Weber, Nietzsche, and Lukács. Fluck argues that instrumental reason can be best understood not as the concern with technical thinking or means-ends rationality (although it certainly encompasses these) but as a way of thinking and acting which have been considered to be hostile to nature, the corporeal, the concrete, and the particular. In this way, he defends the critique of instrumental reason by pointing to its application in global politics, that is, its role of substantive reasoning in the areas of global governance, which may help to shed light on the tensions of promoting responsibility and obligation.

\section{PART III: POLITICAL ECONOMY AND DOMINATION}

The critical research on the global political economy focuses on the tensions and contradictions of the world capitalist system. Critical political economy scholars use a variety of concepts, such as Gramsci's counter-hegemonic bloc, to analyze these contradictions of neoliberalism (i.e., the unequal distribution of resources). By critiquing the neoliberal policies of the privatization of the social sector and regressive tax rates, for instance, they have managed to shed considerable theoretical and empirical light on the modes of resistance to such policies. And yet, what many failed to foresee was the mounting appeal of nationalist populists in the aftermath of the 2008 global financial crisis and the increased flow of refugees due to the effects of war. Right-wing populists, in fact, have managed to appeal directly to mass discontent with these policies (e.g., stagnant wages, economic and social inequality, and the laws accommodating migrant labor rights) and to gain political power in many liberal democratic countries. This, in turn, has led to wide-scale attacks on the rule of law that have destabilized many key institutions. The result has been arguably the greatest crisis facing the liberal international order since the end of the Second World War.

In Chapter 11, Stephen Gill sizes up this new reactionary political trend by examining the intensification and spread of the power of capital and market civilization and how this gives rise to a condition of organic crisis for the people and the planet. Such a crisis constitutes a central problématique for the critical study of IR for the foreseeable future, that is, an intensified struggle for justice concerning the future of 
society, ecology, and world order. Gill distinguishes between the crisis of the global financial order (i.e., that of the world economy after the Wall Street meltdown of 2008) and organic crisis. The latter, as he points out, represents not simply an episodic crisis but a far deeper, multifaceted process. Gill claims that an organic crisis amounts to a threat to the very survival of our planetary ecology and the biosphere. Given the growing political stakes, it presupposes what he calls the "comprehensive problématique of our times."

João Nunes, in his chapter, turns our attention to another challenge of the global political economy: namely, the connection between "security as emancipation" (SAE) and political economy and class. His chapter deals with a specific approach drawn from the Marxist and Frankfurt School traditions to advance a critique of security with explicit emancipatory intentions. Here he develops the idea of SAE and conceives insecurity as the symptomatic constraints placed on human life and freedom, using this idea to unpack one of the SAE assumptions regarding the materiality of security: namely, making the case for what he states is a shift towards the everyday political economy of security. As Nunes suggests, insecurity is built into the neoliberal structures of governance. In recent years, this has been manifested in an equally unsettling development of governance: the emergence of authoritarianism and neoliberalism.

In Chapter 12, Roberto Roccu examines this development through the case of Egypt, where he critically examines the Egyptian uprisings and the extent to which the neoliberal accumulation regime in Egypt emerged, starting in the late 1980s along gradualist and moderate "third wave" lines. Roccu argues that the main donors and transnational corporations (TNCs) that enabled Egyptian elites to implement neoliberal reforms not only transformed the Egyptian economy through integration in global markets, but also created the conditions for neoliberal authoritarianism. Such authoritarianism reflects the greater reliance on coercion, which helps in part to explain the prospects of democratic transformation of an authoritarian regime. Roccu also analyzes the asymmetric, economic, and political regimes (of authoritarianism and democracy) in a global context. The idea here is to bring together two separate bodies of research on international regimes and domestic regimes respectively. As he suggests, emancipation in today's rapidly growing free market global economy not only involves growing counter-resistance to right-wing pluralist pressures, but also the heated political effects of neoliberalism.

Such pressures may be accumulating in a way that so speeds up the economy that it overheats it politically, as Shomik Chakrabarti shows in Chapter 14. In exploring the various counter-political protests inside the United States, Chakrabarti examines these topics under a theoretical lens that observes neoliberal consensus as having "overheated" due to the gradual (over)flow of slow, attritional violence. His approach to these factors demonstrates how labor relations have led to a more precarious, volatile society in which renewed interest in right-wing populist appeals has created a politicized response to the effects of financial boom-and-bust cycles; hence, a disaffected working class and migrant/refugee flows. He concludes that 
these factors have in the end challenged the linear progression of modernity and, by extension, the assumptions of neoliberalism.

\section{PART IV: GLOBAL TRANSFORMATIONS AND CHALLENGES}

IR scholars confront a world in deep crisis. The project of critical IR is to creatively and holistically engage the exclusionary tendencies and effects that fuel such crisis. At the very least, it involves more self-reflection to inform praxis or practical action. Critical IR must, as I and several of the other contributors have maintained, continue to open itself to the world through different forms of self-conscious thought that enable us to work beyond its own limitations and constraints of human agency and modernity or rationality.

In Chapter 15, Steven C. Tauber addresses one of these limitations. Here, he introduces the reader to the implications of integrating critical international theory with the rights and needs of nonhuman animals. For Tauber, the conscious extension of right seeks to overcome what Adorno and Horkheimer theorized in the Dialectic of Enlightenment as human domination or control of nature. Here, Tauber argues that this oversight represents an important gap in critical IR, that is, between human and nonhuman freedom. As he shows, the emerging field of critical animal studies (CAS) can fill this gap by demonstrating the (dead) ends of rationality or how human progress requires humans to brutally oppress animals to serve their own material interests. CAS thus extends the animal studies discipline by employing a critical perspective on the exploitation of nonhuman animals and adopting a multidisciplinary approach to expose the social effects of the mistreatment of animals. CAS, Tauber concludes, can help to expose many of critical theory's anthropocentric assumptions, (e.g., "posthuman" approaches and "green theory"). In this way, critical international theory must better confront the problems of its anthropocentrism by clarifying how CAS connects to critical theory through a focus on emotions of nonhuman animals. This of course means that more creative research needs to be undertaken into the role played by emotion in human affairs and the emancipation from violence.

Like Koschut, Mathias Delori sees emotions as an undertheorized political concept in critical IR. For Delori, there are two central questions that need to be asked, one that pertains to how social actors manipulate the emotions of others in war, the other to how scholars seek to treat emotions not as "objects" but rather as "subjects" of war practices. Much of his focus is trained on how "negative" emotions, such as hatred, anger, or resentment, fostered on all sides the "culture of violence." And yet, as Delori argues in Chapter 16, any consent to violence not only stems from "negative" emotions but also takes root in the neutralization of "positive" ones, particularly compassion. It is this second question that is typically undertheorized. In this way, he analyzes how the role of emotions can become naturalized and/or regulated in ways that allow war and violence to assume a necessary and normalized role in the human 
consciousness. This reveals both the limits and the moral possibilities of reducing violence to negative emotions.

Still, in IR there is a reliance on the neutrality of norms or the application of law to realize these possibilities. The trend towards greater moral accountability is one that pits the neutrality of legal norms against the politics that shaped the application of these norms. Gauging this dynamic process requires the critical interventions of international legal norms to various institutions including the International Criminal Court and the United Nations.

In Chapter 18, Philip Cunliffe discusses the problematic notion of obligation under $\mathrm{R} 2 \mathrm{P}$ (the responsibility to protect). He argues that, in order to read and interpret the concept of R2P critically, it is necessary to realize that assisting others can reinforce R2P's statist logic. Only in certain extreme circumstances of terrible crimes and human suffering can state authority be legally and legitimately limited by outside powers. If this is true, then we still need to confront the regressive logic of R2P, or how R2P represents a paternalistic model of state power and political authority in which political representation is substituted by security or conservative understanding of political responsibility. In this sense, R2P exceeds even the most authoritarian justifications for Leviathan, dissolving the dialectic of reciprocity and representation embedded in contractarian thinking. This, in turn, gives way to a circular theory of state power that can only be justified by reference to itself. In other words, collective transformation tends to lead to protection from the most extreme violence, which, as Cunliffe suggests, is a resolutely exceptionalist justification of political power, one in which power must target the subjects of politically conscious capacity building and inequality.

Raheleh Dayerizadeh examines the transnational challenge of gender inequality in Chapter 17. Dayerizadeh applies these insights to the case of the Iranian Shia women living inside the United States. Here, she discusses the key features of a post-colonial feminist perspective, showing how its critique of liberal non-Western feminism unmasks the effects of the marginalization of non-Western women's movements. In capturing the tension between religion and politics, Dayerizadeh critically examines the experiences of Muslim America, that is, the Shia women who are actively negotiating between Islamic gender complementarity (balance between the genders) and liberal gender norms. She thus argues that, in living in the West, these women are exposed to a variety of gender norms, and that they are consciously choosing from a "basket" of different and sometimes conflicting norms and relating them to their particular social environment and condition.

In sum, critical international theory will continue to face new challenges. Many will require further analysis of the biases (sexual, gender, racial, and anthropocentric) against equality and the related obstacles to realizing justice in world politics. The chapters in this volume offer detailed examinations of how critical IR theory has and will continue to deal with the changing conditions of oppression and to shed theoretical light on the social and political genesis of such biases. 


\section{REFERENCES}

Brincat, Shannon (2014), 'Dialectics in World Politics: The Story Thus Far', Globalizations 11(5): 587-604.

Brincat, Shannon, Laura Lima, and João Nunes (2012), Critical Theory in International Relations and Security Studies. New York: Routledge.

Diez, Thomas and Jill Steans (2005), 'A Useful Dialogue? Habermas and International Relations', Review of International Studies 31, 127-140.

Haacke, Jürgen (1996), 'Theory and Praxis in International Relations: Habermas, Self-Reflection, Rational Argument', Millennium: Journal of International Studies 25(2), 255-289.

Habermas, Jürgen (1984), The Theory of Communicative Action: Reason and The Rationalization of Society. Volume 1. Translated by Thomas McCarthy. Boston, MA: Beacon Press.

Heine, Christian and Benno Teschke (1996), 'Sleeping Beauty and the Dialectical Awakening: On the Potential of Dialectic for International Relations', Millennium: Journal of International Studies 24(2), 404-423.

Horkeheimer, Max (1992), Critical Theory: Selected Essays. New York: Continuum Publishing.

Lapid, Yosef (1989), 'The Third Debate: On the Prospects of International Relations Theory in a Post-Positivist Era', International Studies Quarterly 33(3), 335-354.

Linklater, Andrew (2008), Critical Theory and World Politics. Abingdon, UK: Routledge.

Risse, Thomas (2000), Let's Argue! Communicative Action in World Politics, International Organization 54(1), 1-39.

Roach, Steven C. (2007), 'Critical International Theory and Meta-Dialectics: Fourth Debate or Fifth Dimension?', Millennium 35(2): 321-342.

Roach, Steven C. (2010), Critical Theory of International Politics: Complementarity, Justice and Governance. Abingdon, UK: Routledge. 